\title{
IMPLEMENTASI BLENDED LEARNING DI MASA PANDEMI COVID-19 PADA STIE WIRA BHAKTI MAKASSAR
}

\author{
Indira Basalamah \\ Program Studi Manajemen STIE Wira Bhakti Makassar \\ STIE Wira Bhakti \\ e-mail Indira_Basalamah@yahoo.co.id
}

\begin{abstract}
Abstrak
Produktivitas dosen sebagai hasil belajar merupakan sebuah pencapaian perubahan perilaku individu menjadi lebih baik, mendorong ego-involment dan bermanfaat bagi banyak orang. Hal tersebut dicapai jika kampus mampu berkompetisi dan beradaptasi dengan perubahan teknologi, informasi, dan komunikasi. Saat Pandemi Covid-19 melanda dunia termasuk Indonesia membuat dunia pendidikan harus merubah bahkan memodifikasi metode pembelajaran agar tercapai produktivitas perkuliahan. Blended Learning sebagai enrichment pembelajaran dianggap sangat efektif ditunjang dengan adanya motivasi secara intristik dan ekstristik

Penelitian ini bertujuan untuk mengetahui dan menganalisis pengaruh efektifitas blended learning dan motivasi terhadap produktivitas dosen di STIE Wira Bhakti Makassar. Sampel penelitian adalah Dosen STIE Wira Bhakti Makassar sejumlah 63 orang dan metode analisis yang digunakan adalah analisis regresi berganda dengan program IBM SPSS Statistics. Hasil penelitian menunjukkan bahwa efektivitas metode blended learning dan motivasi berpengaruh positif dan signifikan terhadap produktivitas dosen STIE Wira Bhakti Makassar.
\end{abstract}

Kata Kunci : Efektifitas, Blended Learning, Motivasi dan Produktivitas

\section{Abstract}

Lecturer productivity as a result of learning is an achievement to change individual behavior for the better, encourage ego-involment and useful for many people. This is can be achieved if the campus is able to compete and adapt to changes in technology, information and communication. When the Covid-19 Pandemic hit the world, including Indonesia, the education had to change and even modify learning methods to achieve lecture produktivity. Blended Learning as a learning enrichment is considered very effective supported by intristic and extristic motivation,

The study aims to identify and analyze the effect of blended learning effectiveness and motivation on the productivity of lecturers at STIE Wira Bhakti Makassar. The research sample was 63 lecture of STIE Wira Bhakti Makassar and the analysis method used was multiple regression analysis with the IBM SPSS Statistics program. The results showed that the effectiveness of the blended learning method and motivation had a positive and segnificant effect on the productivity of the lecturers of STIE Wira Bhakti Makassar.

Key Word : Efectivity, Blended Learning, Motivation, and Productivity

\section{PENDAHULUAN}

Ketika WHO menetapkan status Covid-19 menjadi pandemi, tidak akan mengubah cara virus bekerja, namun akan mengubah tatanan seluruh aspek kehidupan baik secara struktur dan system (Setyaka, 2020). Tidak hanya berdampak pada bidang ekonomi, politik, sosial budaya, namun juga terhadap pola pendidikan yang berubah signifikan. Perubahan pola pendidikan ini menurut Rektor Universitas Dinamika Surabaya (Undika) Prof. Budi Jatmiko M.Pd dalam Bhirawa (2020) sebagai suatu 
metamorfisis pola pembelajaran yang semula berada dalam ruang kelas dan tatap muka menjadi pola pembelajaran dengan sistem dalam jaringan (daring).

Transformasi metode pembelajaran secara daring didukung oleh perubahan peradaban digitalisasi yang mengharuskan stakeholder pendidikan harus beradaptasi dengan teknologi dan sistem informasi yang masih menyisakan permasalahan dan kendala yang akhirnya dinilai kurang efektif. Keterbatasan yang dihadapi oleh dosen yaitu ketidaksiapan menerima perubahan secepat ini untuk menggunakan media daring dalam proses belajar mengajar, keterbatasan skill literasi digital (Hamdani dan Priyatna,2020), tidak semua dosen dan mahasiswa memiliki perangkat minimal yang bisa digunakan, dan kualitas koneksi dan ketersediaan paket data (Nuryana, 2020).

Melewati semester awal dimasa pandemic ini dan memasuki era new normal membuat para dosen STIE Wira Bhakti memberanikan diri untuk melakukan proses belajar mengajar secara manual di kampus tanpa mengabaikan protokol kesehatan dan bersamaan pula melakukan tatap muka via daring. Istilah Blended learning lahir sebagai bentuk enrichment pembelajaran untuk melengkapi proses pembelajaran di dalam kelas yang tujuannya agar mahasiswa dapat secara cepat menguasai atau memahami materi perkuliahan yang disampaikan. Materi pembelajaran pun diprogramkan menjadi materi reinforcement sehingga mahasiswa dapat mengulang-ulang materi di mana saja dan pada waktu kapanpun.

Implementasi Blended learning menjadi solusi atas kritik kekurangan perkuliahan daring, akan berjalan dengan efektif jika didukung oleh stakeholder pendidikan termasuk mahasiswa. Berbagai ketentuan social distancing mengharuskan kampus menyediakan dan mempersiapkan ruang kuliah yang steril ditunjang dengan akses internet yang memadai.

Dosen harus memiliki motivasi sehingga proses perkuliahan di masa pandemic ini dapat berjalan dengan efektif. Motivasi adalah suatu kondisi yang menyebabkan timbulnya perilaku tertentu dan memberi arah dan persistence pada tingkah laku tersebut. Dalam proses pembelajaran motivasi punya peran penting baik secara intristik maupun ekstrinstik. Motivasi instristik merupakan hal dasar setiap individu melakukan sesuatu untuk mencapai keinginan atau tujuannya dan didasari adanya dorongan atau rangsangan dari dalam dirinya. Motivasi ini sangat diperlukan bagi dosen karena memiliki kemauan untuk mencapai keinginan mensharing ilmu dan informasi secara langsung. Motivasi ekstristik ada pada individu bila dosen dan mahasiswa menempatkan tujuan pembelajaran di luar faktor-faktor belajar. Dosen dan mahasiswa hendak mencapai tujuan tertentu di luar hal yang dipelajarinya, misalnya harapan mahasiswa untuk memperoleh nilai tinggi diakhir semester dan pencaian kinerja sebagai harapan para dosen. Motivasi ekstristik sangat diperlukan pada kondisi saat ini untuk menumbuhkan minat belajar dan membuat kami menjadi ingin bertindak untuk belajar.

Syahrin (2015) dalam penelitiannya mengemukakan bahwa hasil belajar dengan menggunakan blended learning lebih tinggi daripada menggunakan model konvensional. Hal senada dikemukakan oleh Farihah, dkk (2016) dan Khoiroh, dkk (2017) bahwa hasil belajar dan motivasi dalam mengikuti pembelajaran dengan model blended learning lebih tinggi dibandingkan dengan hasil belajar dengan menggunakan 
metode pembelajaran langsung. Selain itu terdapat interaksi antara pembelajaran blended learning dengan motivasi belajar terhadap hasil belajar.

Produktivitas yang hendak dicapai harus didukung oleh manajemen kampus yang bersedia menerapkan metode pembelajaran ini. Kurangnya dukungan dan minimnya evaluasi akan menurunkan motivasi dalam proses perkuliahan, ditambah dengan ketidakmampuan kampus beradaptasi dengan dinamika teknologi, komunikasi dan informasi. Hal inilah yang perlu dicermati sehingga penulis berkenan melakukan penelitian dengan topik Implemetasi Blended learning di Masa Pandemi Covid-19 pada STIE Wira Bhakti Makassar.

\section{METODE PENELITIAN}

1. Jenis dan Sumber Data. Jenis data yang digunakan dalam penelitian ini adalah data kuantitatif. Penelitian ini menggunakan data primer yang langsung diperoleh dari sumber pertama/perorangan melalui wawancara dan pengisian kuesioner (google form). Perolehan data bersumber dari dosen tetap STIE Wira Bhakti.

2. Populasi dalam penelitian ini adalah Dosen Tetap STIE Wira Bhakti Makassar. Dengan menggunakan metode sampel Sensus seluruh anggota populasi memiliki kesempatan yang sama untuk dimasukan sebagai sampel sejumlah 63 orang (Istijanto, 2016). Untuk menjawab masalah penelitian digunakan teknik analisis regresi linier berganda ( Multiple Regression Analysis). Tujuannya untuk menguji pengaruh antara variabel independen (efektifitas dan motivasi) terhadap variabel dependen (produktivitas).

\section{HASIL DAN PEMBAHASAN}

\section{Hasil}

\section{Uji Asumsi Klasik}

\section{Uji Normalitas}

Untuk mendeteksi kenormalan model regresi yang akan dianalisis dalam penelitian ini menggunakan uji normal probability plot. Teknik dalam uji normalitas ini dilakukan pada nilai residual dalam model regresi dan bukan untuk masing-masing data variabel penelitian. 


\section{Gambar 1. Uji Normalitas}

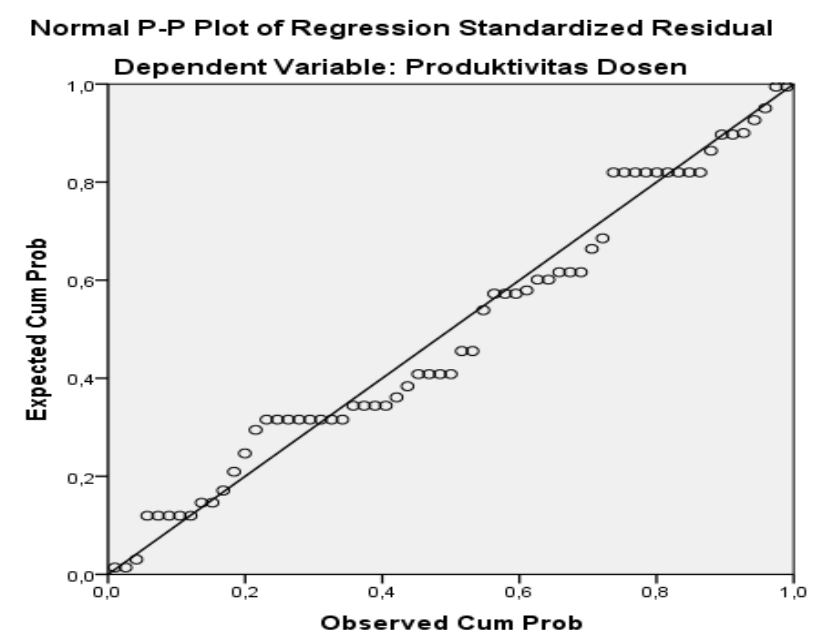

Hasil pengujian menunjukkan bahwa titik-titik ploting atau data berada di dekat atau mengikuti garis diagonalnya. Dengan demikian asumsi normalitas untuk nilai residual dalam analisis regresi linier dalam penelitian ini dapat terpenuhi.

\section{Uji Multikolineritas}

Tujuannya untuk menguji apakah model regresi ditemukan adanya korelasi antar variabel bebas. Model regresi yang baik seharusnya tidak terjadi gejala multikolineritas. Adapun dasar pengambilan keputusan pada uji multikolineritas dengan Tolerance dan nilai VIF (Variance Inflation Factor). Jika nilai Tolerance $>0,10$ maka artinya tidak terjadi multikolinaritas dalam model regresi. Jika nilai Tolerance $<0,10$ maka artinya terjadi multikolenieritas dalam model regresi. Jika nilai $\mathrm{VIF}<10$, maka artinya tidak terjadi multikolineritas dalam model regresi. Jika nilai VIF $>10$, maka artinya terjadi multikolineritas dalam model regresi.

Tabel 1. Uji Multikolineritas

\begin{tabular}{|c|c|c|c|c|c|c|c|}
\hline \multirow[b]{2}{*}{ Model } & \multicolumn{2}{|c|}{$\begin{array}{l}\text { Unstandardized } \\
\text { Coefficients }\end{array}$} & \multirow{2}{*}{$\begin{array}{c}\text { Standardized } \\
\text { Coefficients }\end{array}$} & \multirow[b]{2}{*}{$\mathrm{t}$} & \multirow[b]{2}{*}{ Sig. } & \multicolumn{2}{|c|}{$\begin{array}{l}\text { Collinearity } \\
\text { Statistics }\end{array}$} \\
\hline & $\mathrm{B}$ & Std. Error & & & & Tolerance & VIF \\
\hline 1 (Constant) & 1,727 & ,495 & & 3,489 & ,001 & & \\
\hline Efektifitas &, 325 & 093 &, 370 & 3,509 &, 001 & ,981 & 1,019 \\
\hline Motivasi & ,264 &, 068 & ,407 & 3,862 & ,000 & ,981 & 1,019 \\
\hline
\end{tabular}

a. Dependent Variable: Produktivitas Dosen

Berdasarkan tabel output Coefficients pada bagian Colinearity Statiscic diketahui nilai Tolerance untuk variabel Efektifitas dan Motivasi adalah 0,981 $>0,10$. Sementara nilai VIF untuk variabel Efektivitas dan Motivasi adalah 1,019 < 10. Maka dapat disimpulkan bahwa tidak terjadi gejala multikolinieritas dalam model regresi.

\section{Uji Heterokedastisitas}


Berfungsi untuk menguji terjadinya perbedaan varaice dari nilai residual pada suatu periode pengamatan ke periode pengamatan lainnya dengan melihat pola gambar scatterplots hasil output SPSS.

Gambar 2. Uji Heterokedastisitas

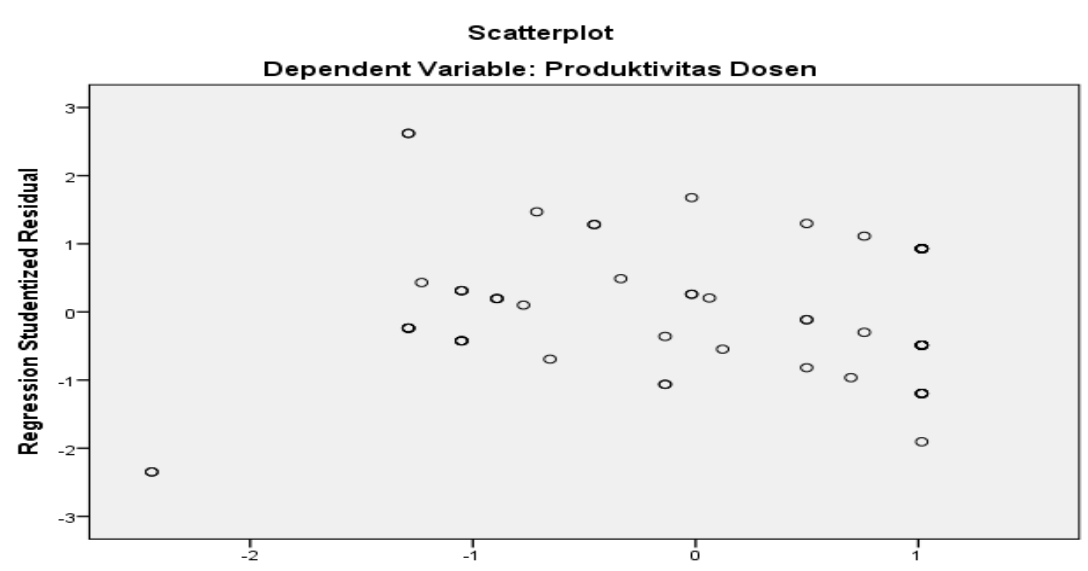

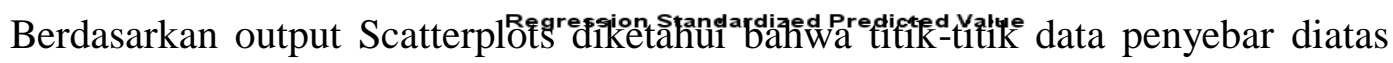
dan dibawah atau sekitar angka 0 (nol). Penyebaran titik-titik data tidak membentuk pola, sehingga dapat disimpulkan bahwa tidak terjadi masalah heterokedastisitas, hingga model regresi yang baik dan ideal dapat terpenuhi.

\section{Uji Regresi Berganda}

Analisis ini digunakan untuk mengetahui arah dan besarnya pengaruh Blended Learning dan Motivasi terhadap produktivitas dosen pada STIE Wira Bhakti Makassar. Hasil pengolahan data berupa persamaan regresi yang tertera pada tabel 2 berikut ini:

\section{Tabel 2. Koefisein Regresi}

\begin{tabular}{|c|c|c|c|c|c|c|}
\hline \multicolumn{7}{|c|}{ Coefficients $^{\mathrm{a}}$} \\
\hline \multirow{2}{*}{\multicolumn{2}{|c|}{ Model }} & \multicolumn{2}{|c|}{ Unstandardized Coefficients } & \multirow{2}{*}{$\begin{array}{c}\text { Standardized } \\
\text { Coefficients } \\
\text { Beta }\end{array}$} & \multirow[b]{2}{*}{$\mathrm{t}$} & \multirow[b]{2}{*}{ Sig. } \\
\hline & & $\mathrm{B}$ & Std. Error & & & \\
\hline & (Constant) & 1,727 & ,495 & & 3,489 & 001 \\
\hline & Efektifitas & ,325 & 093 &, 370 & 3,509 & 001 \\
\hline & Motivasi & ,264 & ,068 & ,407 & 3,862 &, 000 \\
\hline
\end{tabular}

a. Dependent Variable: Produktivitas Dosen

Berdasarkan tabel 2 hasil analisis koefisien regresi diformulakan dalam persamaan regresi sebagai berikut:

$$
Y=1,727+0,325 X_{1}+0,264 X_{2}
$$

1. Apabila variabel Efektifitas (X1) dan Motivasi (X2) bernilai konstan, maka nilai Produktiivitas (Y) akan berubah dengan sendirinya sebesar nilai konstanta 1,727.

2. Koefisien $b_{1}$ menunjukkan 0,325 , artinya setiap peningkatan nilai variabel Efektivitas (X1), maka diharapkan dapat meningkatkan Produktivitas sebesar 32,5\%

3. Koefisien $b_{2}$ menunjukkan 0,264 artinya setiap peningkatan nilai variabel Motivasi (X2), maka diharapkan dapat meningkatkan Produktivitas sebesar 26,4\% 


\section{Uji Hipotesis}

\section{Uji Simultan (Uji F)}

Pengujian secara simultan berguna untuk mengetahui pengaruh variabel Efektifitas dan Motivasi secara bersama-sama terhadap variabel Produktivitas (Y)

Tabel 3 Hasil Ujian F

ANOVA $^{\mathrm{a}}$

\begin{tabular}{|ll|r|r|r|r|r|}
\hline Model & & Sum of Squares & df & Mean Square & F & Sig. \\
\hline 1 & Regression & 4,051 & 2 & 2,026 & 15,747 &, $000^{b}$ \\
& Residual & 7,718 & 60 &, 129 & & \\
& Total & 11,770 & 62 & & & \\
\hline
\end{tabular}

a. Dependent Variable: Produktivitas Dosen

b. Predictors: (Constant), Motivasi, Efektifitas Dosen

Berdasarkan tabel output SPSS di atas, diketahui Nilai $\mathrm{F}$ hitung sebesar 15,747> nilai $F$ tabel 3,15 dengan level signifikansi sebesar 0.000.<0,05, maka sesuai dengan dasar pengambilan keputusan dalam uji $\mathrm{F}$ dapat disimpulkan bahwa Efektivitas (X1) dan Motivasi (X2) secara simultan berpengaruh postif dan signifikan terhadap Produktivitas (Y). Untuk melihat keeratan hubungan antar variabel X (Efektivitas dan Motivasi) dengan Produktivitas (Y) serta seberapa besar kontribusi pengaruh kedua variabel tersebut terhadap Produktivitas, tersaji dalam tabel hasil uji determinasi di bawah ini.

\section{Tabel 4. Hasil Uji Determinasi}

\begin{tabular}{|c|c|c|c|c|}
\hline \multicolumn{5}{|c|}{ Model Summary } \\
\hline Model & $\mathrm{R}$ & R Square & $\begin{array}{l}\text { Adjusted R } \\
\text { Square }\end{array}$ & $\begin{array}{l}\text { Std. Error of the } \\
\text { Estimate }\end{array}$ \\
\hline 1 &, $587^{\mathrm{a}}$ & ,344 &, 322 & ,35867 \\
\hline
\end{tabular}

Tabel diatas menunjukkan bahwa nilai koefisien korelasi $(\mathrm{R})$ sebesar 0,587 yang berarti adanya hubungan yang sedang antara variabel X (Efektivitas dan Motivasi) dengan Produktivitas (Y). Nilai positif menunjukkan hubungan searah dimana variabel efektivitas dan motivasi jika ditingkatkan, maka produktivitas pun akan meningkat. Koefisien determinasi berguna untuk memprediksi dan melihat sumbangan pengaruh yang diberikan variabel independen secara simultan terhadap variabel dependen. Nilai $\mathrm{R}^{2}=0,344$ memperlihatkan besarnya kontribusi kedua variabel $\mathrm{X}$ (Efektivitas dan Motivasi ) terhadap Produktivitas (Y) sebesar 34,4\%. Masih banyak terdapat variabel lainnya yang mampu meningkatkan produktivitas yaitu sebesar 65,6 \%.

\section{Uji Parsial (Uji t)}

Bertujuan untuk mengetahui apakah variabel Efektifitas (X1) dan Motivasi (X2) secara parsial berpengaruh terhadap variabel Produktivitas (Y). Adapun Hipotesis yang diajukan dalam penelitian ini adalah:

1. H1 : Terdapat pengaruh Efektifitas penggunaan metode Blended Learning (X1) terhadap Produktivitas (Y)

2. H2 : Terdapat pengaruh Motivasi (X2) terhadap Produktivitas (Y) 
Berdasarkan tabel Coefficients diatas diketahui nilai t hitung variabel Efektivitas sebesar 3,509 > t tabel 2,000. Tingkat signifikansi variabel Efektivitas (X1) sebesar 0,01 $<$ probabilitas 0,05, maka dapat disimpulkan bahwa hipotesis pertama diterima. Artinya variabel Efektifitas (X1) terdapat pengaruh positif dan signifikan terhadap Produktivitas (Y). Variabel Motivasi (X2) juga memiliki pengaruh positif dan signifikan terhadap Produktivitas (Y) yang diketahui melalui nilai t hitung sebesar 3,862 > t tabel 2,000 dengan tingkat signifikansi variabel Motivasi (X2) sebesar 0,000 < probabilitas 0,05.

\section{Pembahasan}

Untuk menciptakan suasana akademik di masa pandemi Covid-19 ini memerlukan kapabilitas manajemen kampus untuk tetap menyajikan sisitem perkuliahan secara efektif dan efisien. Penyajian materi perkuliahan, metode pembelajaran, dukungan teknologi informasi, dan evaluasi proses pembelajaran dikemas dalam suatu paket yang dapat digunakan dalam metode blended learning. Hasil pengolahan data mengemukakan bahwa variabel efektifitas dan motivasi memiliki pengaruh yang nyata terhadap peningkatan produktivitas dosen. Untuk itu penjelasan pengaruh antar variabel akan diuraikan sebagai berikut:

\section{Pengaruh Efektivitas Blended Learning terhadap Produktivitas}

Penerapan Blended Learning sebagai salah satu metode pembelajaran yang ditempuh oleh dosen STIE Wira Bhakti merupakan pilihan atas ketidakpuasan dosen dan mahasiswa dalam proses mensharing ilmu dan informasi. Khususnya bagi dosen pengampuh mata kuliah yang berkaitan dengan matematika, statistik, akuntansi dan keuangan. Hasil uji regresi berganda menunjukkan efektifitas blended learning berpengaruh positif dan signifikan terhadap produktivitas.

Metode pembelajaran ini sangat efektif diterapkan pada STIE Wira Bhakti di masa Pandemi Covid-19, yang menunjukkan kemampuan kampus untuk beradaptasi dengan perubahan kondisi serta dinamika teknologi informasi dan komunikasi. Kesiapan stakeholder dalam memfasilitasi sarana dan prasarana yang memadai menunjang proses perkuliahan dengan tetap menerapkan protokol kesehatan, mencuci tangan, memakai masker, dan menjaga jarak selama perkuliahan. Untuk menunjang proses pembelajaran daring sekaligus konvensional (tatap muka), kampus menyediakan akses internet tanpa batas sehingga tidak terganggu oleh jaringan yang buruk. Hal utama yang menunjang keefektifan metode blended learning ini adalah kesiapan stakeholder menyediakan anggaran yang cukup besar untuk pelaksanaanya. Tidak sedikit biaya yang digunakan untuk melakukan sosialisasi sejak awal terjadinya pandemi covid-19 yang mengharuskan seluruh aktivitas perkuliahan maupun akademik dilakukan secara daring. Bantuan berupa kuota dari kampus dan Kementrian Pendidikan dan Kebudayaan sangat memotivasi dosen dan mahasiswa untuk beraktivitas.

Kefektifan penggunaan metode blended learning di masa pandemi covid-19 ini sejalan dengan Hamdani dkk (2020) yang menilai kefektifan pembelajaran daring melalui kenyamanan pembelajaran, kemampuan literasi digital, tingkat adaptasi terhadap perangkat, kecukupan perangkat, koneksi internet, biaya pemeblajaran daring, tingkat kenyamanan aplikasi dan komitmen daring pasca pandemi. 


\section{Pengaruh Motivasi terhadap Produktivitas}

Salah satu faktor internal yang mempengaruhi proses belajar adalah motivasi belajar. Jika mahasiswa dan dosen terdorong untuk melakukan aktivitas belajar, maka terjadilah pembelajaran yang efektif. Sadirman dalam Elis (2010) menyatakan bahwa motivasi dapat berfungsi sebagai pendorong usaha dan pencapaian prestasi. Dosen merupakan salah satu faktor eksternal yang mempengaruhi produktivitas belajar dan memiliki peran kunci dalam upaya pendidikan mutu, relevansi, dan efisiensi pendidikan.

Selama pandemi Covid-19 proses pembelajaran dilakukan melalui learning management system sebagai alat interaksi antara mahasiswa dengan dosen. Hasil analisis deskriptif menjelaskan bahwa pembelajaran melalui blended learning menunjukkan besarnya keinginan mahasiswa dan dosen untuk tetap melakukan proses transfer ilmu. Mahasiswa memiliki kemauan belajar yang tinggi terutama mata kuliah perhitungan. Mereka merasa tidak mampu memahami dengan baik materi yang disampaikan oleh dosen secara daring. Di dukungan kesediaan dosen dan pihak kampus maka proses pembelajaran ini terlaksana.

Belajar merupakan kebutuhan bagi setiap insan, bukan hanya sekedar kewajiban maka harus dipenuhi.Melalui belajar akan membentuk pengetahuan, ketrampilan dan sikap seseorang sehingga menjadi insan yang kelak dapat bermanfaat. Walaupun di masa pandemi ini aktivitas pemenuhan belajar terus diupayakan untuk berjalan.

Sebagai tenaga pengajar, dosen juga harus mampu beradaptasi dengan setiap perubahan apalagi dimasa pandemi ini. Pembelajaran daring maupun blended learning merupakan kewajiban yang harus dijalani untuk memenuhi tanggungjawab serta pelaporan sebagai bukti kinerja. Mahasiswa pun demikian, dengan menjalani proses belajar mengajar disaat ini terbesit harapan mereka untuk memperoleh nilai tinggi pada akhir semester.

Motivasi lainnya yang mempengaruhi hasil belajar adalah penilaian yang diberikan dari dosen ke mahasiswa dan dari institusi kepada dosen yang bersangkutan. Memberikan penghargaan maupun pengakuan merupakan suatu apresiasi yang tinggi kepada mereka atas kemauan dan partisipasi untuk memenuhi kebutuhan belajar.

\section{KESIMPULAN}

Berdasarkan hasil penelitian dan pembahasan yang telah dikemukakan, maka kesimpulan dalam penelitian ini sebagai berikut:

1. Efektifitas metode blended learning memberikan pengaruh yang positif dan signifikan terhadap produktivitas dosen di masa pandemi Covid-19 ini. Hal ini menunjukkan bahwa penggunaan metode blended learning dinilai efektif bagi dosen dan mahasiswa dalam mentrasfer pengetahuan, informasi dan pemahaman akan materi perkuliahan.

2. Motivasi memberikan pengaruh yang positif dan signifikan terhadap produktivitas. Adanya motivasi baik secara intristik maupun ekstristik mampu mendorong dosen dan mahasiswa untuk tetap menjalani proses perkuliahan

3. Produktivitas atas hasil belajar secara kontinyu dievaluasi oleh pengelola dan institusi agar proses pembelajaran lebih baik. Dengan memodifikasi metode 
pembelajaran sebagai motivasi agar dosen dan mahasiswa tidak mengalami kejenuhan.

\section{SARAN}

Adapun saran-saran yang dapat diajukan oleh peneliti adalah sebagai berikut:

1. Kampus harus mampu berkompetisi dan beradaptasi dengan segala bentuk sistem informasi teknologi dan komunikasi

2. Dosen harus mampu beradaptasi dengan pembiasaan baru pasca covid -19 dengan memodifikasi metode pembelajaran agar tidak terjadi kejenuhan dan mencapai tujuan pembelajaran.

3. Penelitian ini akan terus berkembang, sehingga peneliti selanjutnya berkesempatan dapat meneliti tentang metode pembelajaran dan pembiasaan baru di pasca pandemi Covid-19.

\section{DAFTAR PUSTAKA}

Aji, Rizqon Halal Syah. Dampak Covid-19 pada pendidikan di Indonesia: sekolah, Ketrampilan, dan Proses Pembelajaran. Jurnal Sosial dan Budaya SYAR-I. Vol. 7 N0. 5.

Bhirawa, Danu. 2020. Metamorfosis Dunia Pendidikan dalam Masa Pandemo Covid-19. https://www.harianbhirawa.co.id/metamorfosis-dunia-pendidikan-dalam-masapandemi-covid-19/

Hamdani, Acep Roni dan Asep Priatna. 2020. Efektifitas Implementasi Pembelajaran Daring (Full Online) di Masa Pandemi Covid-19 pada Jenjang Sekolah Dasar di Kabupaten Subang. Jurnal Ilmiah PGSD STKIP Subang. Vol.VI. No.1

Hilma, Lina Rihatul. Pengaruh Pembelajaran Bauran (Blended learning) Terhadap Motivasi Siswa pada materi Relasi dan Fungsi. Jurnal Ilmiah Pendidikan Matematika. Vol. 2. No1.

Husamah. 2014. Pembelajaran Bauran (Blended Learning) Terampil Memadukan Keunggulan Pembelajaran Face-to Face, Offline-Online dan Mobile Learning. Penerbit : Prestasi Pustaka

Khoiroh, Ni'matul; Muntono; Lilik Anifah. Pengaruh Model Pembelajaran Blended Learning dan Motivasi Belajar Terhadap Hasil Belajar Siswa. Jurnal Penelitian Ilmu Pendidikan. Vol.10. No.2. Hal 97-110.

Manggabarani, Farihah; Sugiarti; Melati Masri. 2016. Pengaruh Model Pembelajaran Blended Learning Terhadap Motivasi dan Hasil Belajar Siswa kelas X SMA negeri 1 Pitumpanua Kab. Wajo. Jurnal Chemica. Vol. 17 No.2 Hal 83-93 


\section{AkMen}

Volume 17 Nomor 4 Desember 2020

Hal. 529 - 538

e-ISSN : 2621-4377 \& p-ISSN : 1829-8524

Hbmepage: https//e-jurnalstienobel-indonesiaacid/indexphp/akmen

Mediawati, Elis. 2010. Pengaruh Motivasi Bellajar Mahasiswa dan Kompetensi Dosen Terhadap Prestasi Belajar. Jurnal Pendidikan Ekonomi Dinamika Pendidikan. Vol. V No. 2. Hal 134-146.

Nuryana, Agus Nana. 2020. Dampak Pandemi Covid-19 Terhadap Dunia Pendidikan. https://kabar-priangan.com/dampak-pandemi-covid-19-terhadap-duniapendidikan/

Setyaka, Virtous. 2020. Covis-19, Deglobalisasi, dan Pasca-Neoliberalisme. https://kabarkampus.com/2020/03/covid-19-deglobalisasi-dan-pasca$\underline{\text { neoliberalisme/ }}$ 